\title{
The solitary pulmonary nodule: Can we afford to watch and wait?
}

\author{
Robert J. Ginsberg, MD
}

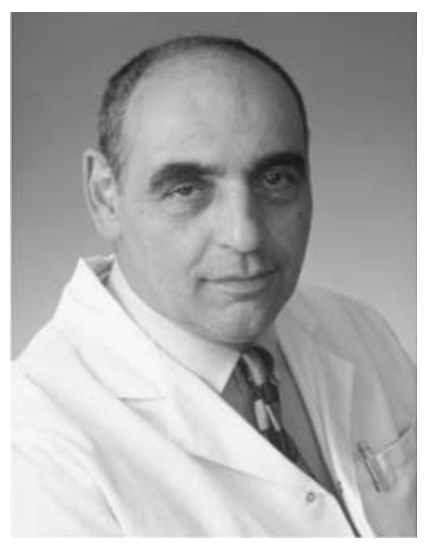

Dr Ginsberg

See related article on page 108.

\footnotetext{
From the Division of Thoracic Surgery, Toronto General Hospital, Toronto, Ontario, Canada.

Received for publication Oct 10, 2001; accepted for publication Oct 12, 2001.

Address for reprints: Robert J. Ginsberg, MD, Division of Thoracic Surgery, Toronto General Hospital, EN 10-226, 200 Elizabeth St, Toronto, Ontario M5G 2C4, Canada.

J Thorac Cardiovasc Surg 2003;125:25-6

Copyright (C) 2003 by The American Association for Thoracic Surgery

0022-5223/2003\$30.00+0

doi: $10.1067 / \mathrm{mtc} .2003 .94$
}

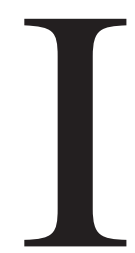

$\mathrm{n}$ this issue Quarterman and associates ${ }^{1}$ address an issue that continues to plague thoracic surgeons. In patients with solitary pulmonary nodules, is it best, as some authors advocate, to excise each and every one of them for diagnosis or can one be selective in proposing excisional therapy to provide a diagnosis? There are many diagnostic options when one encounters such a patient. Imaging techniques, including review of previous radiographs, might allow one to determine conclusively that the lesion in question is benign. For those lesions larger than $1 \mathrm{~cm}$, the use of positron emission tomographic scanning or less invasive transthoracic or transbronchial biopsy techniques can be accurate in up to $90 \%$ of cases so investigated. ${ }^{2}$ The question addressed by these authors is whether watchful observation for a short time is a reasonable alternative, only intervening if this observational period suggests that malignancy is still a possibility.

When one encounters a solitary pulmonary nodule in which previous imaging is not available for comparison, it certainly is reasonable to repeat the imaging procedure in 2 to 3 weeks to ensure that the lesion has not disappeared. Some practitioners advocate a course of antibiotic therapy in conjunction with this.

With the increased use of screening spiral computed tomographic scans and the availability of 3-dimensional (3-D) reconstruction, it is now possible to assess the growth of a lesion within 1 month of identification. Although the size might not increase significantly, the shape of the lesion might alter such that growth can be implied. ${ }^{3}$ This is especially valuable in subcentimeter lesions in which minimally invasive approaches to diagnosis might not be available. It is highly likely, considering tumor doubling time, that most lesions can be identified as potentially malignant with as short a period of observation as 1 to 2 months.

What the authors try to address is, is it harmful to observe lesions for a more extended period of time? Although they do recognize the limitations of their study, their conclusions do suggest that observation for greater than 3 months might not adversely affect cancer survival. Unfortunately, because of the limitations of this study, I do not believe that their conclusions are necessarily valid. As a sideline, it is interesting to note that of the delays greater than 6 months, only one could be attributed to planned observation. However, this article does challenge us to study this question in a more controlled prospective way.

The early reported results of spiral computed tomographic screening studies suggest that in the very tiny $(\leq 5 \mathrm{~mm}$ ) lesions, for which many of the protocols allowed 3-month observation, those patients ultimately given a diagnosis of lung cancer fell mainly into the very early (T1 N0) stage and, at last report, have survived their treatment without tumor recurrence. Too early intervention can be harmful by increasing invasive diagnostic approaches. ${ }^{4}$

What can we conclude from the work of Quarterman and associates? When presented with a patient with a pulmonary abnormality, attempts at early diagnosis should be made whenever possible. However, when watchful observation appears to be the diagnostic approach of choice, the clinician does have the option of a short-term watchful waiting period (ie, the shorter, the better), despite no evidence at the present that a longer waiting time has an adverse outcome effect. 


\section{References}

1. Quarterman RL, McMillan A, Ratcliffe MB, Block MI. Effect of preoperative delay on prognosis for patients with early stage nonsmall cell lung cancer. J Thorac Cardiovasc Surg. 2003;125:108-14.

2. Graeber GM, Gupta NC, Murray GF. Positron emission tomographic imaging with fluorodoxeyglucose is efficacious in evalu- ating malignant pulmonary disease. J Thorac Cardiovasc Surg. 1999;117:719-27.

3. Yankelevitz DF, Reeves AP, Kostis WJ, Zhao B, Henschke CI. Small pulmonary nodules: volumetrically determined growth rates based on CT evaluation. Radiology. 2000;217:251-6.

4. Black WC. Overdiagnosis: an underrecognized cause of confusion and harm in cancer screening. J Natl Cancer Inst. 2000;92:1280-2.

\section{JTCVS On-Line Manuscript Submission and Review Please visit http://www.editorialmanager.com/jtcvs/}

Effective September 15, 2001, authors and reviewers may submit manuscripts and reviews electronically via Editorial Manager, our new Web-based system with full electronic submission, review, and status update capabilities.

As we move from paper to electronic submissions, the Editorial Office will make proxy submissions of all manuscripts accompanied by a diskette containing the electronic files of the text, tables, and figures. Editors, authors, and reviewers will receive automatic e-mails when significant events occur.

We strongly encourage all authors and reviewers to use Editorial Manager. Although we will continue to accommodate the submission of paper manuscripts for some months, our goal is to be completely electronic within 9 to 12 months.

All individuals currently in our database for whom we have e-mail addresses will receive via e-mail a system-assigned username and password that can be used to log in to the system without prior registration. All those not receiving the e-mail must register the first time they use the system.

As with any broad systemic change, the conversion to the new system will take some time to complete. We ask your patience as we replace our in-office database with the new system. We also encourage you to take advantage of the speed and efficiency that the new system will provide for us all: editor, author, reviewer, and publisher. 